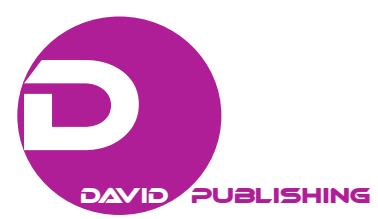

\title{
Mission and Vision Statements of Foundation Universities in the Context of University Roles: A Content Analysis*
}

\author{
İzlem Gözükara \\ İstanbul Arel University, İstanbul, Turkey
}

\begin{abstract}
Higher education institutions are associated with social transformation throughout the history. In this sense, universities, as the most crucial constituent of higher education system, are known to have three main functions, teaching and training, research, and public interest. Today, it is important for these institutions to have a strategic planning with mission and vision statements in order to declare their reason for being and their future goals due to the competitive educational market. The objective of this study was to conduct a content analysis regarding mission and vision statements of foundation universities in the context of university functions. The study included 72 foundation universities from Turkey. Foundation universities do not have a long history in Turkey and strategic planning is still under development in these institutions. The study data were collected from mission and vision statements published on the official websites of the foundation universities. The results of semantic content analysis demonstrated that foundation universities put greater importance on the teaching and training function in their mission and vision messages compared to research and public interest functions. The results of the present study suggest that foundation universities should improve their strategic planning with well-defined mission and vision statements, and should not ignore the other two main functions in this process.
\end{abstract}

Keywords: mission, vision, mission and vision statements, strategic planning, foundation universities, higher education institutions

\section{Introduction}

Since their foundation, higher education institutions have been mutually related with social developments (Martin \& Etzkowitz, 2000). They are regarded to play a key role in social transformation, because they have a substantial influence on such changes and they are concurrently affected by these changes (Brennan, King, \& Lebeau, 2004).

As the prominent higher education institutions, universities are establishments in which scientific research is conducted, solutions are offered to national issues, qualified labor is trained according to the needs of the country, and guidance is provided in terms of democracy and freethinking. This makes universities a key actor in social change. Since these institutions are at the very heart of social transformation, they are also subject to change, which makes them the triggers of transformation.

\footnotetext{
* Acknowledgments: The author would like to thank to Prof. Dr. Ali Akdemir from Istanbul Arel University for his support during this study.

İzlem Gözükara, assistant professor, Department of Business Administration, İstanbul Arel University, İstanbul, Turkey.

Correspondence concerning this article should be addressed to İzlem Gözükara, Türkoba Mah.Erguvan Sok. No:26/K 34537, Tepekent-Büyükçekmece, Istanbul, Turkey. E-mail: izlemg@ arel.edu.tr.
} 
The educational technologies transform and progress, bringing new opportunities and challenges to the higher education system. As a result, universities must overcome new challenges. This is especially significant considering the competitive nature of educational market. This affects teaching and learning aspects of universities due to changing economy and social transformations since, as previously stated, socioeconomic developments have great influence on universities (Siemens \& Matheos, 2010).

Universities are a part of the community which they belong to and the community provides support to these institutions. Their role has doubled in the current century because of the modified conditions. Now, they have to keep their distance from the community in order to be guardians of universal values and reviewer of community, whereas they still have to play their part in socioeconomic, cultural, technological, political, and scientific progress by maintaining their intellectual and scientific attitude.

Universities are places offering new ideas, producing knowledge, designing technology through scientific research, all of which lead to innovation. However, universities are now facing new issues because of financial problems, causing their traditional functions to transform over time. Globalization has caused higher education institutions to reconfigure their systems in order to be global, yet the knowledge economy forces them to remain local at the same time (Cleary, 2002). Within this framework, universities are now considered as saviors of science and knowledge in terms of actuality and fundamentals, questioning, and exploration (Yusof, 2009), rather than just being the single field of knowledge (Klofsten \& Jones-Evans, 2000).

Accordingly, it is highly important for universities to have strategic plans in order to establish their missions and visions. A mission is a concept of existential reason of an institution, while a vision refers to a representative picture of a desired future. Through mission and vision statements, universities build their key principles, determine their future goals, and declare their position and purpose to both their staff and students.

\section{Higher Education and University Roles}

The origin of the modern university dates back to the Age of Enlightenment and the purpose was to promote scientific development, perform logical interpretation, and pursue reality on an institutional basis (Cowen, 1996). Bauman (2001) has verified such history and suggested that, the perceived idea of university and the role of the university are still a paradox of the present day. At the beginning, the modern university emerged from the attempts to reserve an area for generating knowledge independent of church influence (Bayhan, 2009). The doctrine of the Enlightenment suggested that one had the capacity to reach the truth and comprehend oneself using science, and one could even reach happiness through science, as argued by some scholars developing such assumption even further (Harvey, 1990). Nevertheless, such expectations were utopian and subject to change during the history. Economic and historical changes have led higher education institutions to restructure their methods of generating knowledge and providing expertise (Bayhan, 2009).

This contemporary era has caused universities to be identified by the production of knowledge and technology, modernization, and qualified work force, making them involved in enhancing prosperity and create channels for competing in national, regional, and international arenas. The universities' role in socioeconomic progress must be re-evaluated, considering their functions as education suppliers (basic education and continuous labor coaching and advancement), knowledge and technology makers, as well as financial establishments and social players in several fields (Thanki, 1999; Boucher, Conway, \& Van der Meer, 2003). 
University, as defined by Marga (2005; 2009), is an establishment with justification by cultural grounds and with an operative role in its specific context. The university role of this century is to define the higher education context considering present day conditions and find innovative solutions to the issues between education and industry.

Due to historical transformations of university models, the roles of the university have also changed. As of the mid-20th century, universities gained a new social role (applied research, consultancy, and adult training) in addition to their primary education role (Kavak, 1990). The main roles of universities, as listed by Sönmez (2003), include conducting scientific research, problem solving on both a national and universal scale, work force training according to national needs, making their knowledge and expertise available for the public, making publications, and serving as a model.

There are some principles established by Organization for Economic Co-operation and Development (2007) for the assessment of university roles within local and regional development: (1) knowledge production via transferring leading-edge technology and research; (2) knowledge transfer to the community via education and improved human capital; and (3) cultural and social development with the potential to optimize innovative conditions. Whether these principles are satisfied is evaluated by a set of indicators, including: (1) How many affiliations the university has with local and regional players; (2) to what extent the university has innovative contribution via scientific research in its community; (3) how many research centers the university has helped establish; (4) how many major companies the university has led to invest in its region; (5) what is the university's role in creating an action capacity in its region under a highly competitive global economy; (6) what is the university role in human resources development; and (7) to what extent the university has made social, cultural and environmental contributions. The starting point of establishing all these criteria can constitute the university's mission statement. However, this brings the requirement of defining "the mission of the university" and its functions (Marga, 2010). A mission statement is a specific declaration that should be prepared by each university, and the extent of its exercise can vary on a local, regional, national, and international basis.

As previously stated, universities are beneficial players contributing to development, knowledge production and transfer, and innovation (Goddard, Robertson, \& Vallance, 2012). These institutions try to fulfill such intentions by means of three roles: teaching $\&$ training, research, and public interest. These roles are the subject of an important discussion related to higher education system; however, the underlying concept is still unclear and each university may have its own concept based on its activities, position within the region and the national plan of the country (Sánchez-Barrioluengo, 2014).

According to the widely recognized opinion of Pawlowski (2009), an entrepreneurial university keeps a solid relation with the society and the economic setting, yet such relation is only based upon the university's internal progress. If this university form is expanded into a complicated model with transformational attempts for its region via socioeconomic, cultural, and educational actions, as well as collaboration with diversified establishments of the region involved, then it assumes that such university must undergo a fundamental transformation as a result of this synergy (Marga, 2010).

Researchers have an increasing passion toward an entirely distinct perspective for the university roles and they have started concentrating not just on the education and research functions, which has resulted in a fourth role (Trencher, Yarime, McCormick, Doll, \& Kraines, 2014). Specifically, the demand from the 
universities is to be open systems in connection with their environment and to explore effective commitments with other parties, which may include district administrations, industry, civilian population, or development agencies (Lukman, Krajnc, \& Glavic, 2009; Peer \& Stoeglehner, 2013). Trencher et al. (2014) believed that this "co-creation for sustainability" is a novel university role. This can only be achieved by building a sophisticated communication system among academicians and other players of the community (Adomßent, 2013), and such system ensures a shared commitment for determining the demand of knowledge, conducting researches, generating knowledge, providing reflexive learning, and transferring knowledge (Peer \& Stoeglehner, 2013).

In this context, Etzkowitz, Webster, Gebhardt, and Terra (2000) conducted a study to assess the collaboration among universities, state, and industry given the fact that the information society has led universities to have an enhanced role. They investigated the extent of such collaboration in different states and concluded that a new way was required for the future studies and the universities had to make their long-term policies, if they wanted to embrace an entrepreneurial spirit. The study by Azman, Sirat, and Azhari (2010) conducted a survey to evaluate the position and functions of Malaysian higher education, especially the universities. There were various scenarios in this survey for the future Malaysian higher education, including the status and role considering the preferences of their country. As another example, Ritzen (2006) built scenarios about how higher education would function in the future from an international perspective as to the dynamism of higher quality talents around the world. Higher education was shown to be an international entity and international expertise was suggested to be a favorable resource for scientific and political efficiency. Considering the improvement in the Information and Communication Technology (ICT) and the new opportunities offered to everyone regarding information, Atkins (2005) suggested that this improvement has the potential to create a breakthrough for the future higher education. Additionally, the recent study by Mellow and Woolis (2010) examined the global tendencies and leading effects that would be of importance for the future higher education and concluded that there were three major aspects: globalization, progress in technology, and influence of the market.

\section{Higher Education in Turkey}

The Turkish higher education has been under a strong influence of the state throughout its history (Ercan, 1998). According to Tekeli (2003), Turkish universities did not advance simultaneously with those of the Western countries, due to the relatively delayed emergence of the university concept. Higher education institutions are currently subject to the Council of Higher Education (YÖK) in Turkey, which is an institution founded in 1982 after the enacting of the Law of Higher Education (No: 2547) in 1981.

The founding purposes of YÖK were planning, guiding, and managing the activities of higher education system. The single actors were the state universities prior to YÖK (Atakan \& Eker, 2007). Upon the introduction of this institution, non-profit organizations were allowed to establish foundation universities. In 1981, the first foundation university was established and followed by several foundation universities up to the present.

In state universities, students are only required to pay a tuition fee for education, which is much higher in foundation universities. Nevertheless, state and foundation universities have many differences beyond mere expense. State universities have limited budgets with the government funding compared to foundation universities that have monetary resource from tuition fees. This causes foundation universities to have an 
opportunity of improved resources, cutting-edge materials, and improved educational equipment (Atakan \& Eker, 2007). The ratio of academician-student is lower in the foundation universities, too (Tansel \& Gungor, 2002).

Foundation universities have a limited history of only 20 years and the quality of their education system is still under improvement. This is why the foundation universities are in an ongoing search for the best academicians in the respective fields of teaching and research and they continually attempt to find new fields to distinguish themselves from their rivals, try to provide improved resources of teaching and learning, and create exclusive social opportunities for their students (Atakan \& Eker, 2007).

The teaching and research concept of higher education has been transformed in Turkey and "performance" has become a prominent notion for the higher education debate, as proven by the analyses of Lyotard (1984). Also, the reports of YÖK (2007) and Turkish Industrialists and Businessmen Association (2000; 2003; 2006) regarding higher education in Turkey have highlighted the performance notion and strictly recommended that universities should focus on performance, while planning their budgets, evaluating their personnel, and improving research activities.

There are 193 universities in Turkey as of 2015. Among these, 114 are state universities and 76 are foundation universities based on the statistics provided by YÖK on its official website.

\section{Mission and Vision}

The globalization of the world has emerged a reorganization necessity for higher education, which is gradually moving away from the public sphere toward a semi-public identity (Şenses, 2007; Altınsoy, 2011; Türk Eğitim Derneği, 2011; Acar, 2012). Today, especially due to progress in information technologies, educational institutions are in a rapid transformation as is the case with all fields. Having an important place in the national development, the universities' function of providing a quality teaching and training service is becoming more critical in a transforming world. This necessitates strategic plans prepared for ensuring quality and planning future to be more vital (Arabacı \& Şener, 2014).

Strategic planning constitutes the initial stage of strategic management. Strategic management refers to the choices and activities during policy-making for designating the organization's future performance (Wheelen \& Hunger, 2012). Strategic management allows organizations to establish their working objectives and an informed and diligent approach is required to fulfill them (Güçlü, 2003). As the first step of strategic management, strategic planning is an organization's process of defining and planning its strategies in order to adapt to its environment and minimize the risks, of which the importance has been emphasized by many scholars (Robinson, 1982; Powell, 1992; Boyd \& Elliott, 1998).

Articulating a mission and vision statement is of critical significance for effective strategic planning (Özdem, 2011). Strategic planning can be successful only if the mission and vision statements are defined and developed accurately (Devlet Planlama Teşkilatı, 2006). In this sense, there are important clues about the type of teaching-training service provided in mission statements within the strategic plans prepared by universities during the foundation stage (Kunt, 2012).

A mission statement articulates the "reason for being" of an institution. It is the response of the institution to "what is our business? why do we exist? what are we trying to accomplish?" (Bart, 1997, pp. 9-18). According to Kemp and Dwyer (2003), an effective mission statement should define the objective, products and services, doctrine, fields, and core technology of an institution. An institution must construct such 
mission statement as part of its strategic management process (David, 2001). If an organization does not have a shared view describing its goals, it becomes a "traveler" without any idea where to go (Ackoff, 1987), because the institution cannot determine its improvement process without a clearly defined mission. Therefore, a mission statement should aim to designate the institution's merits, ideas, and ground rules to exhibit performance and define the connection with its personnel, clients, investors, state, and community (Ackoff, 1987).

A vision, the second item of strategic planning, refers to the institution's insight for the future. Vision represents an explicit understanding of the current and future positions. It reflects an institution's purpose, which has an influence over all institutional elements, and it is increasingly highlighted as an integral part of strategic management in today's world. A vision is an institution's desire and behavior of conduct (Dinçer, 2006). A vision is a product of a reasonable and logical mind for ways of implementing an optimal future. An institution's vision should be pragmatic, cost-effective, technology-based, ambitious, and managerial should consider potential social issues and should be based on its capacity and resources (Alt1ok, 2011). Institutions should not pursue a vain hope or a dream while creating their visions. In fact, a strategic vision should challenge the institution to formulate its activities and create a dynamism for its strategy (Thompson \& Strickland, 1999). According to Thompson and Strickland (1999), the best vision statements are those having a clear guideline for the operational direction of the institution. According to Cowley and Domb (2012), a vision statement delivers inspiration and authority for everyone involved in that organization. In brief, a vision statement is a way for an organization to reflect its future and predict its goal, which makes it become a commitment of a brand. Finally, Kotter (2012) described vision as an organization's forecast of its future position and vision statement as the description of reasons for pursuing such future to the members of that institution, in an open or an implied way.

There are several studies analyzing the mission and vision statements of universities. The study by Velcoff and Ferrari (2006) consulted 35 senior executives in universities to establish the extent to which mission statements were consistent with university activities. They found a positive correlation between mission statements and university activities. Another research by Morphew and Hartley (2006) involving approximately 300 colleges/universities (both state and public) concluded that state and private universities/colleges had different wording in their mission statements compared to those most commonly used. Firmin and Gilson (2010) analyzed the mission statements of 107 universities/colleges and found that the most common topics were educational matters, religion, community, life, and university, and confirmed that colleges/universities declared their reason of existence through mission statements. The study by James and Huisman (2009) from Wales concluded that the mission statements of higher education institutions were not consistent with the regional policies and were not in line with the market intentions. Özdem (2011) examined the mission and vision statements of public universities in Turkey and reported that the most frequent mission statement was on education of a qualified workforce, whereas the vision statements most commonly focused on research function.

\section{Data Collection and Analysis}

The study data were collected from the mission and vision statements of 72 foundation universities, which were published on the universities' official websites. The statements were analyzed using semantic content analysis. 
First, the official websites of the foundation universities were checked for mission and vision statements. The findings were classified into five groups based on the presence and/or absence of mission and vision statements. These groups included universities with no mission and vision statements, universities with no mission statements, universities with no vision statements, universities with no separation between mission and vision statements, and the universities with mission and/or vision statements.

Second, the mission and vision statements were analyzed using semantic content analysis according to three main categories that were established based on the core functions of universities: teaching-training, scientific research, and public interest. The messages in the mission and vision statements were classified under these three main sub-categories. Each category had varying number of messages, which were carefully determined not to contain the same context and to be distinctive in nature. The number of the messages in each sub-category, which was expressed by the foundation universities in their mission and vision statements, was calculated and expressed in both frequency $(f)$ and percentage $(\%)$. This method revealed the most common statements of mission and vision in each sub-category for the foundation universities. The frequency analysis made on the thematic analysis helped comprehend the significance and concentration of the messages under a category.

\section{Results}

This section will first provide the findings on five groups of foundation universities regarding the presence and/or absence of mission and vision statements. This will be followed by the findings on the content of mission and vision statements. The mission and vision statements were analyzed based on the sub-categories in the definitions.

The first analysis of the mission and vision statements revealed that there were $10(f=10,13.89 \%)$ universities that had no mission and vision statements, one $(f=1,1.38 \%)$ university that had no mission statement, one $(f=1,1.38 \%)$ university that had no vision statement, six $(f=6,8.33 \%)$ universities that did not make any separation between mission and vision statements, and $60(f=60,83.33 \%)$ universities that had mission and/or vision statements.

Based on the content analysis, the distribution of the mission and vision statements of foundation universities by sub-categories is presented in Table 1. Accordingly, the total number of messages was 187 in mission statements and 110 in vision statements. When the sub-categories were examined, the highest number of messages was in the "services for teaching and training" in both mission and vision statements $(f=75$, $40.1 \%$ and $f=62,56.4 \%$, respectively). The lowest number of messages was in the "services for public interest" again in both mission and vision statements $(f=55,29.4 \%$ and $f=18,16.4 \%$, respectively). The third sub-category of "services for research" was mentioned in 57 (30.5\%) mission statements and 30 (27.3\%) vision statements. Among all these three sub-categories, mission statements had higher number of messages than those in the vision statements.

The distribution of mission and vision messages under the "services for teaching and training" sub-category is presented in Table 2. Among a total of 137 messages (75 in mission and 62 in vision statements), "international standard (world class) education" was the most commonly used message $(f=28,20.43 \%)$. This message was used by 12 universities in mission statement and 16 universities in vision statement. The second common message was "education of individuals with leadership/entrepreneurship spirit" $(f=20,14.59 \%)$, which was mentioned in 13 mission statements and seven vision statements. The third most common message 
was "education of individuals who are critical and free thinkers, innovative and creative" $(f=19,13.86 \%)$, and used by a higher number of universities $(f=13)$ in mission statement than in vision statement $(f=7)$. The least mentioned message was in "education of high-quality human resource" and "education of individuals with sense of social responsibility (community service)" ( $f=4,2.91 \%$ for both). In these two sub-categories, the foundation universities' messages were mentioned only in the mission statements, not in the vision statements $(f=4$ and $f=0$, respectively).

Table 1

Distribution of Mission and Vision Statements of Foundation Universities by Sub-categories

\begin{tabular}{lllll}
\hline \multirow{2}{*}{ Sub-categories of messages in the mission and vision definitions } & \multicolumn{3}{c}{ Mission } & \multicolumn{2}{c}{ Vision } \\
\cline { 2 - 5 } & $f$ & $\%$ & $f$ & $\%$ \\
\hline Services for teaching and training & 75 & 40.1 & 62 & 56.4 \\
Services for research & 57 & 30.5 & 30 & 27.3 \\
Services for public interest & 55 & 29.4 & 18 & 16.4 \\
\hline
\end{tabular}

Table 2

Mission and Vision Statements Under the Sub-category of Services for Teaching and Training

\begin{tabular}{|c|c|c|c|c|}
\hline \multirow{2}{*}{$\begin{array}{l}\text { Messages in the sub-category of } \\
\text { "services for teaching and training" }\end{array}$} & \multirow{2}{*}{$\begin{array}{l}\text { Mission } \\
f\end{array}$} & \multirow{2}{*}{$\begin{array}{l}\text { Vision } \\
f\end{array}$} & \multicolumn{2}{|c|}{ Total } \\
\hline & & & $f$ & $\%$ \\
\hline Education of qualified individuals at national and universal levels & 6 & 2 & 8 & 5.83 \\
\hline National/international academic recognition & 3 & 8 & 11 & 8.02 \\
\hline International standard (world class) education & 12 & 16 & 28 & 20.43 \\
\hline Education of individuals with leadership/entrepreneurship spirit & 13 & 7 & 20 & 14.59 \\
\hline Education of individuals who are critical and free thinkers, innovative, and creative & 13 & 6 & 19 & 13.86 \\
\hline Providing scholarship/financial support to successful students & 2 & 3 & 5 & 3.64 \\
\hline Providing physical infrastructure/developing current conditions & 2 & 3 & 5 & 3.64 \\
\hline Education of high-quality human resource & 4 & 0 & 4 & 2.91 \\
\hline Support for interdisciplinary studies & 6 & 6 & 12 & 8.75 \\
\hline Education of individuals with sense of social responsibility (community service) & 4 & 0 & 4 & 2.91 \\
\hline Adopting quality education and total quality management principles & 6 & 5 & 11 & 8.02 \\
\hline Being a center of excellence and attraction & 4 & 6 & 10 & 7.29 \\
\hline
\end{tabular}

Table 3 presents the distribution of mission and vision statements under the "services for research" sub-category. There were 57 messages in mission statements and 30 messages in vision statements. Among them, "contribution to science and technological development in the world and in our country" had the highest number of messages in mission and vision statements $(f=19,21.83 \%)$. This message was followed by "having technological infrastructure and equipment" $(f=12,13.79 \%)$, "being a pioneer in research at national/international level (being at the top)" ( $f=10,11.46 \%)$, and "education of exploring and questioning scientists" ( $f=10,11.46 \%)$. The least commonly used messages were "being a research university", "national/international recognition in research", and "university-industry cooperation" $(f=4,4.56 \%$ for all). When analyzed individually, "contribution to science and technological development in the world and in our country" was the most common message in mission statements $(f=14,24.56 \%)$ compared to "being a pioneer in research at national/international level (being at the top)" in vision statements $(f=6,16.66 \%)$. The lowest number of messages was "national/international recognition in research" in mission statements $(f=1,1.75 \%)$ 
and "knowledge generation and implementation (analysis and synthesis)" was not mentioned by any of the university in their vision statement $(f=0,0.00 \%)$.

Table 3

Mission and Vision Statements Under the Sub-category of Services for Research

\begin{tabular}{lrrrr}
\hline Messages in the sub-category of & Mission & Vision & Total \\
\cline { 2 - 5 } "services for research" & $f$ & $f$ & $f$ & $\%$ \\
\hline Being a pioneer in research at national/international level (being at the top) & 4 & 6 & 10 & 11.49 \\
Being a research university & 2 & 2 & 4 & 4.59 \\
National/international recognition in research & 1 & 3 & 4 & 4.59 \\
Education of exploring and questioning scientists & 7 & 3 & 10 & 11.49 \\
Contribution to science and technological development in the world and in our country & 14 & 5 & 19 & 21.83 \\
Having technological infrastructure and equipment & 7 & 5 & 12 & 13.79 \\
University-industry cooperation & 3 & 1 & 4 & 4.59 \\
Supporting entrepreneurship & 4 & 2 & 6 & 6.89 \\
Contribution to national development through scientific research and publications & 4 & 3 & 7 & 11 \\
Knowledge generation and implementation (analysis and synthesis) & 11 & 0 & 12.64 \\
\hline
\end{tabular}

Table 4

Mission and Vision Statements Under the Sub-category of Services for Public Interest

\begin{tabular}{|c|c|c|c|c|}
\hline \multirow{2}{*}{$\begin{array}{l}\text { Messages in the sub-category of } \\
\text { "services for public interest" }\end{array}$} & \multirow{2}{*}{$\begin{array}{l}\text { Mission } \\
f\end{array}$} & \multirow{2}{*}{$\begin{array}{l}\text { Vision } \\
f f\end{array}$} & \multicolumn{2}{|c|}{ Total } \\
\hline & & & $f$ & $\%$ \\
\hline Professional competence in the national/international area & 2 & 0 & 2 & 2.73 \\
\hline Contribution to the economic/cultural/social/technological development of society & 12 & 1 & 13 & 17.80 \\
\hline Education of individuals with sense of social responsibility & 15 & 5 & 20 & 27.39 \\
\hline Pioneering social advancement/social development & 6 & 8 & 14 & 19.17 \\
\hline Conducting studies for human benefit & 10 & 2 & 12 & 16.43 \\
\hline Enhancing and advancing the qualified workforce of the country & 6 & 1 & 7 & 9.58 \\
\hline Education of environment-conscious youth & 4 & 1 & 5 & 6.84 \\
\hline
\end{tabular}

The distribution of mission and vision statements under the sub-category of "services for public interest" is presented in Table 4, the messages of which were found in 55 mission and 18 vision statements. Regarding mission statements, the most common message was "education of individuals with sense of social responsibility" ( $f=15,27.27 \%)$ and the least common message was "professional competence in the national/international area" ( $f=2,3.63 \%)$. While none of these messages in this sub-category were excluded from the mission statements, very few were observed in the vision statements. The most common message was "pioneering social advancement/social development", mentioned by eight universities (44.44\%). There were no messages in "professional competence in the national/international area" ( $f=0,0.00 \%)$. When the messages were analyzed collectively, "education of individuals with sense of social responsibility" $(f=20,27.39 \%)$ was the most common as it was in the mission statements. The second most common message was "pioneering social advancement/social development" $(f=14,19.17 \%)$, followed by "contribution to the economic/cultural/social/technological development of society" $(f=13,17.80 \%)$ and "conducting studies for human benefit" $(f=12,16.73 \%)$. Finally, the lowest number of messages was in "professional competence in the national/international area" $(f=2,2.73 \%)$. 


\section{Discussion}

The present study aimed to analyze the mission and vision statements of foundation universities in Turkey in the context of university roles. Study data were collected from the mission and vision statements on the official websites of the universities and semantic content analysis was used to determine the primary messages under three core functions of universities.

The findings showed that foundation universities put the greatest emphasis on the function of teaching \& training highest and the least emphasis on public interest in both mission and vision statements. However, "education of individuals with sense of social responsibility", which was included in public interest, was the most frequent and "national/international recognition in research", which was included in research, was the least frequent message among a total of 187 messages observed in the mission statements. The foundation universities mentioned "international standard (world class) education" most, which was included in teaching \& training, in a total of 110 messages given in the vision statements. Contrary to mission statements, vision statements had no messages in more than one sub-categories of all three main functions. Furthermore, the total number of messages in vision statements was lower than mission statements in all three categories, and a great majority of the vision statements concerned the function of teaching \& training.

A mission statement expresses the reason for existence of an institution. It simply describes the institutional identity and the institution's specific features differentiating it from other institutions. The Turkish law also requires universities to have a strategic plan with mission and vision statements. However, the results of this study demonstrate that foundation universities do not fully comply with this regulation. The findings revealed that there are foundation universities which have no mission or vision statements, or which have made no effort to prepare separate mission and vision statements. The results also suggested that foundation universities give priority to their teaching $\&$ training roles in their mission statements. Besides, foundation universities do not seem to place due emphasis on recognition in research.

A vision statement, in turn, provides a representative picture of the future. It describes the way of implementing an optimum future for the institution and it is an essential part of strategic planning. The present study has demonstrated that foundation universities in Turkey are not concerned about vision statements as much as mission statements. The number of messages contained in vision statements is relatively low and universities fail to address certain sub-categories (e.g., "professional competence in the national/international area" and "knowledge generation and implementation"). However, universities most frequently emphasize their "international standard (world class) education" under the teaching \& training function, which contains the highest number of messages among all three main categories. Consequently, the priority of foundation universities in Turkey has been observed to be the role of teaching \& training in both mission and vision statements.

\section{Conclusions}

Mission and vision statements are essential parts of strategic planning. Today, strategic planning is considered vital for all institutions including universities especially due to the globalizing and competitive environment. Universities are important higher education institutions with three core functions of teaching \& training, research and public interest. In this regard, universities are required to use this process to declare their institutional identities and future desires under today's competitive conditions. Due to their specific organizational structure, foundation universities may greatly benefit from the mission and vision statements. 
Through these statements, foundation universities can develop positive relationships with their academic staff, students, and society. They can describe their unique attributes and their visions for an optimal future.

The present content analysis of mission and vision statements of foundation universities shows that foundation universities generally prefer using similar messages in their statements, which are mostly about teaching \& training. In this sense, it would be beneficial for universities to diversify the content of their messages in a way that would include the two other main functions: research and public interest. Since universities are the core of scientific research, it is surprising that only $30.48 \%$ of the mission messages and $27.27 \%$ of vision messages fall in this category. This paper recommends future studies to investigate this specific finding in detail using respective variables including but not limited to the number of projects, academic publications, and academic staff.

The results of the present study demonstrate that foundation universities give the lowest priority to public interest. This is also an interesting finding considering that universities have been instrumental in national/social development since their foundation. Unfortunately, it appears that new foundation universities in Turkey are expressing little concern with social welfare. This may be due to the dynamics of the country and cultural structure, or due to the relatively short history of such universities.

In light of the findings of the present study, this paper recommends foundation universities to review their mission and vision statements based on the correct formulation of strategic planning. It also recommends universities to place more emphasis on the two other critical functions of universities since all three core functions are considered equally important. For future studies, it recommends more research on mission and vision statements in higher education institutions, since there is limited research in this field. In this sense, the present study contributes to the literature. However, this study is limited to the analysis of mission and vision statements of foundation universities. Future studies may include state universities and make comparisons. Other fields of future research may include the analysis of entire strategic plans of foundation universities without being limited to mission and vision statements, the comparison of universities' performance with the strength of their strategic plans, and the effect of universities' mission and vision statements on their stakeholders including their academic staff and students. Finally, it recommends future studies to analyze the three functions of universities separately by comparing their mission and vision statements.

\section{References}

Acar, M. (2012). Üniversitelerde yeniden yapılanmanın aciliyeti ve yeni üniversitelerin sorunları (The emergency of reconstruction in universities and the problems of new universities). Eğitime Bakış Dergisi, 8(23), 21-27.

Ackoff, R. (1987). Mission statements. Planning Review, 15(4), 30-31.

Adomßent, M. (2013). Exploring universities' transformative potential for sustainability-bound learning in changing landscapes of knowledge communication. Journal of Cleaner Production, 49, 11-24.

Altınsoy, S. (2011). Yeni devlet üniversitelerinin gelişimi: Sorunlar ve politika önerileri (Development of new public universities: Problems and policy recommendations). Yükseköğretim ve Bilim Dergisi, 1(2), 98-104.

Altiok, P. (2011). Applicable vision, mission and the effects of strategic management on crisis resolve. Procedia Social and Behavioral Sciences, 24, 61-71.

Arabacı, İ. B., \& Şener, G. (2014). Üniversitelerin misyon ifadelerinin tematik olarak incelenmesi (The thematic examination of universities' expressions of mission). Kastamonu Eğitim Dergisi, 22(2), 701-716.

Atakan, M. G., \& Eker, T. (2007). Corporate identity of a socially responsible university - A case from the Turkish higher education sector. Journal of Business Ethics, 76(1), 55-68.

Atkins, D. E. (2005). University futures and new technologies: Possibilities and issues (Unpublished discussion paper for an OECD expert meeting). 
Azman, N., Sirat, M., \& Azhari, M. K. (2010). Building future scenarios for Malaysian universities. Journal of Asia Public Policy, 3(1), 86-90.

Bart, C. (1997). Sex, lies, and mission statements. Business Horizons, 40(6), 9-18.

Bauman, Z. (2001). The individualised society. Malden, MA: Blackwell Publishers Inc.

Bayhan, S. (2009). Recontextualisation of higher education in turkey: A discourse analysis of higher education strategy report for Turkey (Thesis for master of arts in educational sciences, Boğaziçi University).

Boucher, G., Conway, C., \& Van der Meer, E. (2003). Tiers of engagement by universities in their region's development. Regional Studies, 37(9), 887-897.

Boyd, B. K., \& Elliot, E. R. (1998). A measurement model of strategic planning. Strategic Management Journal, 19(2), 181-192.

Brennan, J., King, R., \& Lebeau, Y. (2004). The role of universities in the transformation of societies (An international research report).

Cleary, J. (2002). The entrepreneurial university and the learning economy in a regional context. Retrieved from http://www.aair.org.au/app/webroot/media/pdf/AAIR\%20Fora/Forum2002/ Cleary.pdf

Cowen, R. (1996). Performativity, post-modernity and the university. Comparative Education, 32(2), 245-258.

Cowley, M., \& Domb, E. (2012). Beyond strategic vision. Hoboken: Taylor and Francis.

David, F. (2001). Strategic management concepts (8th ed.). Upper Saddle River, NJ: Macmillan.

Devlet Planlama Teşkilatı. (2006). Kamu idareleri için stratejik planlama kılavuzu (Strategic planning guidelines for public administrations). Ankara: Yazar.

Dinçer, Ö. (2006). Stratejik yönetim ve işletme politikası (Strategic management and management policy) (8th ed.). İstanbul: Alfa Yayım Dağıtım.

Ercan, F. (1998). Eğitim ve kapitalizm: Neoliberal eğitim ekonomisinin eleştirisi (Education and capitalism: A critic of neoliberal education economy). Istanbul: Bilim Yayıncılik.

Etzkowitz, H., Webster, A., Gebhardt, C., \& Terra, B. R. C. (2000). The future of the university and the university of the future: Evolution of ivory tower to entrepreneurial paradigm. Research Policy, 29(2), 313-330.

Firmin, M., \& Gilson, K. M. (2010). Mission statement analysis of CCCU member institutions. Christian Higher Education, 9, 60-70.

Goddard, J., Robertson, D., \& Vallance, D. (2012). Universities, technology and innovation centres and regional development: The case of the Northeast of England. Cambridge Journal of Economics, 36(3), 609-627.

Güçlü, N. (2003). Stratejik yönetim (Strategic management). G.U. Gazi Eğitim Fakültesi Dergisi, 23(2), 61-85.

Harvey, D. (1990). The condition of postmodernity: An inquiry into the origins of cultural change. Cambridge, Mass.: Blackwell Publishing.

James, H., \& Huisman, J. (2009). Missions statements in Wales: The impact of markets and policy on congruence between institutions. Journal of Higher Education Policy and Management, 31(1), 23-35.

Kavak, Y. (1990). Kalkınmada öncelikli yörelerdeki yüksek öğretim kurumlarının çevreye dönük faaliyetleri (The environment-directed activities of higher education institutions in development priority regions). Ankara: TOBB Yayınlar1.

Kemp, S., \& Dwyer, L. (2003). Mission statements of international airlines: A content analysis. Tourism Management, 24, 635-653.

Klofsten, M., \& Jones-Evans, D. (2000). Comparing academic entrepreneurship in Europe-The case of Sweden and Ireland. Small Business Economics, 14(4), 299-309.

Kotter, J. P. (2012). Leading change. Boston: Harvard Business School Press.

Kunt, Ş. (2012). Türkiye'de üniversitelerin stratejik planlarındaki misyon, vizyon ve stratejik amaçların içerik analizi (The content analysis of mission, vision and strategic goals of universities in Turkey in their strategic plans) (Unpublished master's thesis. Çukurova University, Adana).

Lukman, R., Krajnc, D., \& Glavic, P. (2009). Fostering collaboration between universities regarding regional sustainability initiatives. Journal of Cleaner Production, 17(12), 1143-1153.

Lyotard, J. F. (1984). The postmodern condition: A report on knowledge. Minneapolis: University of Minnesota Press.

Marga, A. (2005). University reform today (3rd ed.). Cluj-Napoca: Presa Universitară Clujeană.

Marga, A. (2009). Challenges, values and vision: The university of the 21st century. Cluj-Napoca: Presa Universitară Clujeană.

Marga, A. (2010). Analiză diagnostic. Universitatea úi valorile sociale. Retrieved from http://edu2025.ro/UserFiles/File/LivrabileR1/diagnostic_panel4.pdf

Martin, B. R., \& Etzkowitz, H. (2000). The origin and evolution of the university species. Vest, 13, 9-34.

Mellow, G. O., \& Woolis, D. D. (2010). Teetering between eras: Higher education in a global, knowledge networked world. On the Horizon, 18, 308-319. 
Morphew, C., \& Hartley, M. (2006). Mission statements: A thematic analysis of rhetoric across institutional type. The Journal of Higher Education, 77(3), 456-471.

Organisation for Economic Co-operation and Development (OECD). (2007). Higher education and regions: Globally competitive, locally engaged. Retrieved from http://www.oecd.org/document/25/0,3343,en_2649_201185_39329177_1_1_1_1,00.html

Özdem, G. (2011). Yükseköğretim kurumlarının stratejik planlarında yer alan vizyon ve misyon ifadelerinin analizi (An analysis of the mission and vision statements on the strategic plans of higher education institutions). Kuram ve Uygulamada Eğitim Bilimleri, 11(4), 1869-1894.

Pawlowski, K. (2009). The "fourth generation university" as a creator of the local and regional development. Higher Education in Europe, 34(1), 51-64.

Peer, V., \& Stoeglehner, G. (2013). Universities as change agents for sustainability—Framing the role of knowledge transfer and generation in regional development processes. Journal of Cleaner Production, 44, 85-95.

Powell, T. C. (1992). Strategic planning as competitive advantage. Strategic Management Journal, 13(7), 551-558.

Ritzen, J. (2006). Scenarios for higher education, 2020 or when will China invade Iran? Proceedings from The OECD Ministerial Meeting.

Robinson, R. B. (1982). The importance of outsiders in small firm strategic planning. Academy of Management Journal, 215(1), 80-93.

Sánchez-Barrioluengo, M. (2014). Articulating the "three-missions" in Spanish universities. Research Policy, 43, $1760-1773$.

Şenses, F. (2007). Uluslararası gelismeler ısığında Türkiye yükseköğretim sistemi: Temel eğilimler, sorunlar, çeliskiler ve öneriler (Turkish higher education system in consideration of international developments: Basic trends, issues, conflicts and suggestions) (Economic Research Center, working paper in economics 07/05, pp. 1-31, Middle East Technical University, Ankara).

Siemens, G., \& Matheos, K. (2010). Systemic changes in higher education. Education: Technology \& Social Media, 16(1), 3-18.

Sönmez, V. (2003). Yüksek öğretimin yeniden yapılanması üzerine bir deneme (An essay about the reconstruction of higher education). Ĕgitim Araştırmaları, 12, 4-12.

Tansel, A., \& Gungor, N. D. (2002). Brain drain from Turkey: Survey evidence of student non-return. Career Development International, 8(2), 52-69.

Tekeli, İ. (2003). Dünya'da ve Türkiye'de üniversite üzerinde konuşmanın değişik yolları (Various ways of talking about universities in the world and Turkey). Toplum ve Bilim Dergisi, 97, 123-134.

Thanki, R. (1999). How do we know the value of higher education to regional development? Regional Studies, 3(1), 84-88.

Thompson, Jr. A. A., \& Strickland III, A. J. (1999). Strategic management; concepts and cases (11th ed.). Boston, Mass.: Irwin Mc Graw Hill.

Trencher, G., Yarime, M., McCormick, K. B., Doll, C. N. H., \& Kraines, S. B. (2014). Beyond the third mission: Exploring the emerging function of co-creation for sustainability. Science and Public Policy, 41, 151-179.

Türk Eğitim Derneği. (2011). Yükseköğretimin yeniden yapılandırılması: Görüş ve öneriler (Reconstruction of higher education: Opinions and suggestions). Ankara: Türk Eğitim Derneği.

Turkish Industrialists and Businessmen Association. (2000). Yükseköğretimin finansmanı: Yasal düzenleme için öneriler (Financing of higher education: Recommendations for legal regulations). Retrieved from http://www.tusiad.org/tusiad_cms.nsf/LHome/EBEDEDC88FE6E247C225733E0025473B/\$FILE/yuksekogretim.pdf

Turkish Industrialists and Businessmen Association. (2003). Yükseköğretimin yeniden yapılandırılması: Temel ilkeler (Reconstruction of higher education: Basic principles). Retrieved from http://www.tusiad.org/tusiad_cms.nsf/LHome/4D98AA3DBB82FC75C225733E00419630/\$FILE/yok.pdf

Turkish Industrialists and Businessmen Association. (2006). Eğitim ve sürdürülebilir büyüme: Türkiye deneyimi, riskler ve firsatlar (Education and sustainable growth: Turkish experience, risks and opportunities). Retrieved from http://www.tusiad.org/tusiad_cms.nsf/LHome/AF46C33B133445B9C225733E0046AF5F/\$FILE/No9.pdf

Velcoff, J., \& Ferrari, J. (2006). Perceptions of university mission statement by senior administrators: Relating to faculty engagement. Christian Higher Education, 5, 329-339.

Wheelen, T. L., \& Hunger, J. D. (2012). Strategic management and business policy toward global sustainability (13th ed.). Upper Saddle River: Pearson Education/Prentice Hall.

YÖK. (2007). Türkiye'nin yükseköğretim stratejisi (Higher education strategy for Turkey). Ankara: Meteksan A.Ş.

Yusof, M. B. (2009). Organizational antecedents of academic entrepreneurship in public research universities: A conceptual framework. Unitar E-Journal, 5(2), 33. 